\title{
Distinctive marketing strategies of different industries in India
}

\author{
Rahul Gupta Choudhury \\ International Management Institute (IMI) \\ Bhubaneswar, Odisha, India
}

Keywords

Marketing strategies, Consumer Durables, FMCG, India

\begin{abstract}
Different firms follow different strategies. It is partially dependent on the industry they operate in. The objective of the study is to find out whether there are similarities between firms operating in the same industry sector in terms of strategy. Another subsequent objective is to look at the similarities in strategy undertaken by firms in the same industry sector and whether and how the strategies pursued by firms in different industry sectors are different. The study was carried out in India. It was found that there are lot of commonalities in strategy between firms operating in the same industry sector. Also, strategies pursued by firms in different industry sectors are distinctly different. There are certain strategic factors like price and quality which are common to all industry sectors. The bottom line is that consumers want value and firms has to provide value, the composition and factors comprising value differs according to the industry the firm operates in.
\end{abstract}

\section{Introduction}

Industry is divided into various sectors depending on the products or services they produce. All firms have the primary objective of fulfilling the needs of its customers/consumers. In order to do this, they adopt strategies which encompass the various functions of the firm. Now, these strategies are different for different firms, and they differ from industry to industry. This is primarily because of the difference in needs of customers of different firms in diverse industries, as well as the macro-economic environment. Not every firm in a given industry follow the same strategy, but there is an underlying similarity in strategic outlook of firms in the same industry. These strategies are, again, different for firms in different industries. It is the intention of this study to identify the strategic differences among diverse industries. There has been a lot of deliberation on whether firm-specific strategy is more relevant than industry strategy. The concepts of SCP (structure-conduct-performance) and the RBV (resource-based view) has for a long time dominated the discourse on the functioning and performance of firms and industries. At an aggregate level, there are many similar strategies that firms belonging to a particular industry follow, irrespective of the firm's position in the industry. Normally it is observed that in any given industry, there are outstanding performers who elevates the overall performance of the industry. Then there are average performers and still further down are the laggards who pull down the performance of the industry. The methodology of this study precludes the consideration of firm-level differences and, instead, highlights the overall differences among industries in terms of strategy (primarily marketing).

There is no doubt about the fact that different firms pursue different strategies - as strategies are made on the basis of the internal as well as the external environments that the firms face. The firms operate within a given industry and there are certain given characteristics of the industry as well. As has been discussed earlier, there has been considerable debate and discussion on whether firm-specific attributes or industry characteristics have a more important role to play in deciding about the strategies to be pursued by the firm. This study, however, does not enter into that debate. This study is more interested in finding out whether certain aspects of strategies pursued by firms in different industries are different. That means, firms belonging to a certain industry will pursue different strategies compared to those of firms belonging to a different industry. The study considers certain aspects of the overall strategies of firms belonging to a certain industry and compares that with those aspects of the strategies being pursued by firms belonging to other industries. So, the primary objective of the paper is to unearth and compare the distinctively different strategies pursued by firms operating in different industries. The differences in strategy are at the industry level and not firm-specific. 


\section{Objective \& research method}

In order to understand the strategies pursued by these firms, a study was conducted with the help of a detailed structured questionnaire. The questionnaire was sourced from literature. It is divided into the following ten sections: background, market, target audience, competition, offering, sales and buying process, pricing, strategy issues, impact of marketing strategy, and marketing strategy decisions. In the questionnaire, questions were formulated on a wide range - from markets to quality as well as $\mathrm{R} \& \mathrm{D}$. The objective was to ascertain the direct as well as indirect impact of business strategy on various aspects of the functioning of the firm - from defects and waste to inventory, from customer management to personnel, and from labor to risk management. A particular area is devoted to questions pertaining to product, from design to development, and from technology to performance. Strategic competitive goals were also discussed wherein questions were asked regarding particular marketing strategies like lower selling prices, distribution, product, delivery, advertisement, and sales promotion.

However, this paper will enumerate the strategic differences on the following factors only: market opportunity and size, customer's basic need and primary reason for buying, competitive activities, distinction with competitors and barriers to entry in the marketplace, improvements in offerings, pricing and value delivery, and industry trends. These factors enabled us to ascertain whether there are distinct strategies being conceptualized and implemented by different types of firms, depending on the industry they belong to. The idea was to understand, for example, whether firms in consumer durable industry have different sets of business and/or marketing strategies compared to firms in the industrial products category.

In order to establish these differences in strategy, responses or answers were required from executives of organizations who were aware of the strategic direction of their firms and the consequent results they have obtained. The responses were obtained by administering a detailed questionnaire to top executives (mostly, General Managers and above) of companies operating in India. The questionnaire has a combination of open as well as close ended questions, such that executives were not required to divulge confidential information on the one hand, and on the other hand, no constraints were put on them in terms of answering questions they feel they need to answer in detail. Analysis of their responses established the direction and magnitude of distinctiveness of strategies being undertaken by different sets of firms operating in India.

The study encompasses firms across the entire spectrum of Indian industry. There are some associations of Indian industries like Confederation of Indian Industries (CII) and ASSOCHAM, which has membership of different kinds of firms across the country. The members of these associations are among the top-rated firms in the country and fairly reliable in their systems and processes. CII has approximately 7000 members and ASSOCHAM has about 4500 members. Some memberships are common. The questionnaire was pretested on some executives and some members of the academia as well. It was administered to top executives of these firms through e-mail. Initially, the recipients were all firms listed in the membership of CII. So, a total of 7000 firms, who were members of CII and ASSOCHAM received email invitations to participate in the survey. The target firms were of all sizes and came from almost all major industries in India. Reminders were sent to the target firms after a gap of 15 days. A total of 105 complete responses were received from the target sample of 7000 firms. However, the responses from firms were a fair representation of the Indian industry.

Out of the 105 responses received, 33\% were from foreign owned businesses, and 67\% were from domestic businesses. Industry wise break-up of responses are the following: 5\% from FMCG, 9\% from Consumer Durable, 33\% from Industrial Products, $8 \%$ from Software, 3\% from Pharmaceuticals, 2\% from Telecom, 4\% from Banks, 3\% from Automobiles, and 34\% from Services. The method obtained for identifying the industry in cases where it is a well-diversified conglomerate was that the respondent was requested to respond on the basis of the product-market (division) which contributed the most to the revenues or profits of the corporate entity.

\section{Analysis}

The analysis of this survey is more qualitative in nature than quantitative.

Consumer companies report that price is a very important factor for their customers. It is observed that price is of greater significance for FMCG products compared to consumer durables. Consumer 
companies feel that the customer today is more concerned about value rather than price per se. However, shift in price points create instability in the market and the brands take their price change decisions based on the market leader or the price leader in the category. Quality of the product, especially in the consumer durable category, plays a very important role in the purchase decision of their customers. Customers are not willing to make any compromises in the trade-off between price and value - they want the best possible value at the least possible price. For the MNCs in the consumer marketing space, India is a price sensitive market, but most customers would prefer value over price. The trade-off between price and value is made only when the quality of the product is very high. A few consumer companies also feel that product features and brand are more important than price. This may be true for a range of high-end products. Most Software companies consider price as one of the most important criteria for sales. However, MNCs have the same opinion that India is still a very price sensitive market. Some customers of software products prefer value over price, and for some customers - the skills and the scope of the work matter more than just price. In the software industry, time taken for a project and the design is also a crucial factor.

In the pharmaceutical industry as well, price is important - but so is reputation. It is not very clear as to the composition of this reputation, but a valid premise would be the effectiveness or quality of the products. Some of the customers in this industry are value oriented as well. In the intensely competitive telecom market, price is of major importance. As one company in the telecom industry observed, value is delivered by constantly lowering the operating cost. This means, the companies try to minimize the total cost of running the business - the amortization of capital expenditures plus the operating expenditures. The banking sector also feels that price is very important. Some banks are of the opinion that customers give more importance to pricing of their products than value. In the automobile sector, customers at the entry level are very price sensitive. However, as the customers move up the ladder in terms of better quality and higher priced products, the price sensitivity keeps coming down. So, only customers at the bottom of the hierarchy of products and price are price sensitive. This sensitivity is very low at the upper stages of the hierarchy of products and price. In case of Industrial products, the scenario is slightly different. A very large number of industrial product manufacturing firms are of the opinion that price is not so important as compared to value. Customers in this category look for quality and performance; some of them are more prone to considering service quality as one of the most important criteria for making a purchase. Some companies in this category say that price is very critical as the purchasing officer is evaluated on the amount of reduction of cost, he is able to achieve. In some cases, there are regulatory issues which takes precedence over prices.

For many MNCs, the entry route is through pricing only. This gives them a foothold in the market. However, sustaining and growing the business is possible only through the value route. For some customers in this product category, reputation and track record is more important than price. The rest of the respondents or companies are mostly from the service industry. A small percentage of this sector said that price is the most important factor and is almost critical for their customers' decision. However, this subgroup is very small in number. Most of the service sector is of the opinion that for most customers, value is more important. Some customers have a budget, and they want to optimize their purchases in order to remain within their budgets. The reason for this behavior is that most of it is institutional business. For some customers, time taken to complete a project is of paramount importance. For companies in the hotel industry, the brand or some other value-added service is the differentiator. For those in the education or similar sector, like consultancy, value is of prime importance. Time is a very important criteria for some customers. When the job has to be done on priority, the importance of price in the decision-making process comes down considerably. In this category, time and quality often get as much or more importance than price. 
Table 1: Importance of Pricing \& other Factors

\begin{tabular}{|l|l|}
\hline Product Category & Important Components \\
\hline FMCG & Very important; Determined by market leader or price leader in the category; \\
\hline Consumer Durables & Value more important; Quality more important; Product features \& brand; \\
\hline Software & Very important; Value; Skills \& scope of work; Time taken \& design; \\
\hline Pelecom & Important; Reputation; Some are value oriented; \\
\hline Banks & Very important; constant lowering of operating cost; \\
\hline Automobiles & Very important - more than value; \\
\hline Industrial Products & High sensitivity at entry level; Very little at higher levels; \\
\hline Service Industry & Value more important than price; Quality \& performance; Reputation \& track record; \\
\hline
\end{tabular}

The respondents were also asked about the factors that could drive prices up or down. In the consumer industry, the main factor is competition. Almost all companies in this category talked about intense competition. Consumer durables companies went a step further and talked about macro-economic factors impacting prices. Technology also plays an important role. Companies with the latest technologies drive prices down. Prices of raw materials is obviously an important component impacting prices. Another factor bringing down prices is the growth of the middle class which is increasing consumption at a rapid pace - thus bringing down prices. In the software industry, apart from competition, the factor impacting the prices are the state of the client organizations/industry. This means, Software companies who are vendors of automotive companies, are finding it difficult to maintain prices as the automotive industry is moving towards more of "low maintenance costs" cars. In the pharmaceutical industry, price changes are determined by raw material prices and competition. In the telecom industry, prices are determined by the innovative use of existing resources. The more innovative the use, more the efficiency which leads to lowering of prices. In the banking sector, prices are dependent on government rates driven by RBI. It is also dependent on the expenditures of the bank vis-à-vis profits earned. In the automobile sector, prices are impacted by manufacturing efficiencies including technology. Service revenues of OEMs also influence the pricing in the automobile sector. There are various perspectives in Industrial products category as this category is an amalgamation of varied types of industries - with different products and markets. Some of the companies talk about competition and technology, some others about exchange rates, and still others about investments in infrastructure. For some companies in this category, volumes determine the prices. Raw material prices influence prices, and then there is the real danger of commoditization. Macro-economic factors along with regulations also determine prices for some companies. In the service industry, demand supply gap along with technology and competition impacts prices. Raw materials are also an important factor. Some service industry companies talked of customer stickiness and brand recognition as well.

\begin{tabular}{|l|l|}
\hline Product Category & Factors \\
\hline FMCG & Competition; \\
\hline Consumer Durables & $\begin{array}{l}\text { Competition; Macro-economic factors; Technology; Prices of raw materials; } \\
\text { Growth of middle-class; }\end{array}$ \\
\hline Software & Competition; State of the client organization/industry; \\
\hline Pharmaceuticals & Competition; Raw material prices; \\
\hline Telecom & Innovative use of existing resources; \\
\hline Banks & Government rates - RBI; Expenditure vs profits; \\
\hline Automobiles & Manufacturing efficiencies; Technology; Service revenues of OEMs; \\
\hline Industrial Products & $\begin{array}{l}\text { Competition; Technology; Exchange rates; Investments in infrastructure; Volumes; } \\
\text { Raw material prices; Commoditization; Regulations; Macro-economic factors; }\end{array}$ \\
\hline Service Industry & $\begin{array}{l}\text { Competition; Technology; Demand supply gap; Raw material prices; Customer } \\
\text { stickiness; Brand recognition; }\end{array}$ \\
\hline
\end{tabular}

Conference proceedings of the Centre for Business \& Economic Research, ICGEEE-2020, 10-12 December 
The respondents were then asked about the primary reason for buying or wanting to use their product or service. FMCG companies all talked about their product. The companies were of the opinion that it is the right kind of product for their target customers that made the customers buy their product. The consumer durable companies felt that the good quality of their products and the good quality of their service motivated the consumers to buy their products. On-time delivery is also one of the important factors for their customers to purchase their products. For MNCs in the consumer durable space, localization of their products is very important. In the software industry, the key factor is service - service which helps their client organizations to run or perform better. The other important factors are pricing or value, quality design concept, and core domain knowledge. The pharmaceutical industry is almost unanimous that the most important factors are quality and service. Price also does play an important role sometimes. For the telecom industry, the important factors for the customers to buy their products are uniqueness and efficiency. In the banking sector, the important factors are trust and better service. Competitive pricing also sometimes becomes important in this sector. The customers of automobiles buy the product only because world class technology is provided at very competitive pricing. The overwhelming response from the industrial products category is that their customers buy from them because they produce high quality products and provide excellent service. Quality and service are the core reasons for customers buying their products. Some of them did mention that prices or value is also important sometimes. However, many companies, especially MNCs, are of the opinion that brand matters. Customers buy from them because they have a good brand name in addition to the essential features of quality and service. The most important factors in the service industry is quality, and service and sometimes, price. One of the distinguishing features of this category is that these companies must be able to improve the operating parameters of the client organization. Hence some of them get the outsourced work of very large organizations. So, naturally, the client organization expects them to do the job better than if they had done it themselves. They try hard to improve the efficiency and effectiveness of the systems operating in the client organizations. Since many of these companies are in B2B situations, it is also very important to form long term business relationships with their clients.

Table 3: Reasons for Buying

\begin{tabular}{|l|l|}
\hline Product Category & Factors \\
\hline FMCG & Product - Right fit with target segment; \\
\hline Consumer Durables & Quality; Service; On-time delivery; For MNCs - Localization of products; \\
\hline Software & Service; Pricing/value; Quality design concept; Core domain knowledge; \\
\hline Pharmaceuticals & Quality; Service; Price; \\
\hline Telecom & Uniqueness; Efficiency; \\
\hline Banks & Trust; Service; Competitive pricing; \\
\hline Automobiles & World class technology; Competitive pricing; \\
\hline Industrial Products & Quality; Service; Price; Brand; \\
\hline Service Industry & $\begin{array}{l}\text { Quality; Service; Price; Improve operations of clients; Efficiency \& effectiveness; } \\
\text { Long-term business relationship; }\end{array}$ \\
\hline
\end{tabular}

The respondents were then asked about the barriers to entry into the marketplace that they are creating for other businesses. The following table summarizes their responses:

Table 4: Barriers to Entry

\begin{tabular}{|l|l|}
\hline Product Category & Factors \\
\hline FMCG & $\begin{array}{l}\text { Cost competitive expertise; Product innovation; Better relationship with customers } \\
\text { \& motivated sales team; }\end{array}$ \\
\hline Consumer Durables & Very low entry barriers; Customization; Investments; Technicalities and service; \\
\hline Software & First mover's advantage; low cost; High ROI for customers; \\
\hline Pharmaceuticals & $\begin{array}{l}\text { Better quality products and timeliness of service; Capital expenditure in fixed } \\
\text { assets resulting in innovative products, larger range, better packaging }\end{array}$ \\
\hline Telecom & First to market; Project gestation delay; Integration of customized software; \\
\hline Banks & Government restrictions; Capital requirements; \\
\hline Automobiles & Exclusive OE tie-ups; \\
\hline
\end{tabular}




\begin{tabular}{|l|l|}
\hline Industrial Products & $\begin{array}{l}\text { Low cost and consistent quality; High working capital and infrastructure cost; } \\
\text { Customization \& customer relations; Cost leadership; Fast response and wide } \\
\text { supplier network; Product innovation; Brand; Intellectual property; Maintenance; } \\
\text { Technology; }\end{array}$ \\
\hline Service Industry & $\begin{array}{l}\text { Investments in technology; Patented products; Relationship with customers; Price } \\
\text { \& service levels; Quality; Contracts with customers; Regulatory restrictions; Strong } \\
\text { brand; Reputation; Difficulty of customer acquisition; }\end{array}$ \\
\hline
\end{tabular}

\section{Conclusion}

The paper has highlighted the differences among firms across various industries on some very certain parameters related to strategy. Looking back, there are certain commonalities as well. Price is important across all industries. The pricing of products and services are driven by competition, but the primary reason why consumers buy from the firms is quality. So, the traditional concept of price, competition and quality stands good even today. The firms do try to create barriers to entry and the primary barrier in many industries is the requirement of high investments. The similarities, however, ends there. The industries vary widely in their strategy pertaining to pricing as well as in giving their customers some solid reasons for buying their products. It is observed that customers are more sensitive to prices in the low-priced product categories compared to the higher priced categories. There are lots of strategic parameters on which customers base their decisions and thus enforce the industries to provide these same parameters in the products and services that companies produce and supply. It is no longer a scenario of only producing quality products at reasonable prices. Now, price and quality are hygiene factors. Companies has to really provide value, in order to attract and retain customers. This value is defined in different ways by customers belonging to different industries. It is for the industry to identify and understand these needs and wants and then provide them to the customers.

\section{References}

Rein, Shaun, Lessons for Chinese companies as they are global, BusinessWeek Online, Dec 2008. http://www.businessweek.com/globalbiz/content/dec2008/gb2008121_644935.htm

Athreye, Suma \& Kapur, Sandeep, Introduction: The internationalization of Chinese and Indian frims- trends, motivations, and strategy, Industrial and Corporate Change, Vol 18, Number 2, pp 209 - 221, Feb 24, 2009.

Chi, Ting, Business Contingency, Strategy Formation, and Firm Performance: An Empirical Study of Chinese Apparel SMEs, administrative sciences, 2015, 5, 27-45.

Prange, Christiane \& Bruyaka, Olga, Better at home, abroad, or both? How Chinese firms use ambidextrous internationalization strategies to drive innovation, Cross Cultural \& Strategic Management, 2016, Volume 23, Issue 2, pp 306-339.

Liu, Xuefeng \& Wu, Xiaobo, Technology embeddedness, innovation differentiation strategies and firm performance: Evidence from Chinese manufacturing firms, Innovation: Management, Policy \& Practice, Volume 13, Issue 1, April 2011.

Gao, Xudong, Effective Strategies to Catch Up in the Era of Globalization: Experiences of Local Chinese Telecom Equipment Firms, Research Technology Management, 2011.

Quer, Diego, Claver, Enrique \& Rienda, Laura, Cultural distance, political risk, and location decisions of emergingmarket multinationals: a comparison between Chinese and Indian firms, Journal of the Asia Pacific Economy, 2017, VOL. 22, NO. 4, pp. 587-603. 